\title{
Determination of Recreation and Tourism Use Value of Bozcaada by Travel Cost Analysis Methods
}

\author{
Rukiye Duygu Çay*, Tülay Cengiz Taşlı \\ ${ }^{1}$ Trakya University Faculty of Architecture Department of Landscape Architecture, Edirne, Turkey \\ ${ }^{2}$ Çanakkale Onsekiz Mart University Faculty of Architecture and Design Department of Landscape Architecture, \\ Çanakkale, Turkey
}

Received: 6 February 2020

Accepted: 10 April 2020

\begin{abstract}
In this study, Travel Cost Analysis is used to make an economic valuation of recreational area for the Bozcaada, NW Turkey. Within this framework, a total of 200 questionnaires were applied to the visitors at Bozcaada by the random sampling method. In the economic analysis model of Bozcaada, the "Number of Visits" made to the area per year was taken as the dependent variable, while "Travel Expenses", "Participants' Level of Income", "Age of participants" and "Vehicle Ownership Status" were taken as independent variables. Semi-logarithmic function type was used for the analysis of consumer rent. As a result of the analyzes, total consumer rent value was found to be 21.795.492,32 TL per year considering Bozcaada's September 2017 prices. In this research, the relationship between the landscaping areas and the economy is revealed and it is exemplified that the economic analysis of the environment and sources can be made by Individual Travel Cost Method (ITCM).
\end{abstract}

Keywords: individual travel cost method, consumer's surplus, recreation, economic valuation, Bozcaada

\section{Introduction}

The presence of environmental assets and natural components in urban areas contributes to the quality of life of people in many ways. In addition to environmental services, natural areas provide social and psychological services that are essential for the livability of modern cities and the well-being of the city residents [1].

*e-mail: rduygucay@trakya.edu.tr
The evaluation of recreational value is the monetary accounting of extensive benefits from an economic point of view. It is also an expression of people's willingness to pay, which reflects an extensive assessment of the entertainment experience, ecological environment, sensory enjoyment and spiritual harvest [2].

Classification of Ecosystem Services (CES) is an important class of cultural ecosystem benefits services, recreational ecosystem services (RES) benefit people through improved physical health, and psychological and emotional well-being [3]. Recreation opportunities also provide an economic basis for communities and related businesses [4]. Kulczyk, Woźniak [5] stated 
that recreational ecosystem services (RES) are the most often assessed cultural ecosystem services [6, 7]. Boerema, Rebelo [8] has determined that most RES studies focus on monetary value.

Ecosystems have various dimensions that are important for social welfare with their biophysical, sociocultural and economic features [9]. Ecosystems provide a mix of non-market services and recreation experience, as well as services traded in markets as well as free access to the recreation area [10].

The concept of ecotourism is to engage in tourism activities in order to generate income for the protected area. Therefore, the economic assessment of a region plays an important role in the development and management of ecotourism [11]. Paying attention to the management and protection of the recreation area can increase opportunities for earnings and employment [12].

According to Heslinga, Groote [13], nature-based tourism is not only a socio-economic activity that provides income and other benefits to local communities, but also plays an important role in understanding natural heritage, gaining public support and funding for protection [14, 15]. Fredman and Tyrväinen [16] stated that nature-based tourism is mostly associated with leisure activities taking place in natural areas, and its main components are visitors and experiences in nature. These experiences can be different and include a variety of outdoor activities [17].

Island tourism is an important commercial quest that meets the needs of its participants with natural and produced resources determined in certain geographical areas. In particular, the term "island tourism" refers to the integration of the island's natural spots and urban developments, advancing the establishment of tourism on an island, family guesthouses, corporate hotels and other related commercial areas. This may affect the island's local population growth, environmental improvement, completion of facilities, and functional improvement [18].

Economic valuation of environmental resources is important for many reasons, such as the importance of assessing environmental damage, providing green national accounts, imposing taxes and fees for control and preventing the destruction of entertainment centers [19].

The absence of a specific market for the environmental assets and the lack of economic evaluation result in an erroneous determination of the value of benefits derived from the use of nonmarketable assets [20]. Economists have long ignored the economic value of natural resources assuming that their supply is limitless. However, the fact that the supply of environmental resources and the self-renewal capacity are limited has been acknowledged only after the 1980s and it began to be accepted that they should be seen as scarce resources [21].

The fact that consumers are unaware of the benefits they gain from using non-market assets leads to the indiscriminate use of such assets. This will lead the environmental assets such as forests, agricultural land, and rivers to decrease or even disappear. When economic values of non-market assets are determined, users will tend to use the natural resources more judiciously and the future generations will benefit more from these environmental assets [20]. Individuals have to make a choice between what they will consume or give away in the direction of the socioeconomic structures, which is also the main theme of the economy. The most rational behavior in this choice is the proper ordering of preferences that provide the most satisfaction for the consumption of limited resources. The expected benefit of adapting this function of the economy to the natural and environmental issues is the social welfare that will emerge eventually by the protection and improvement of the environment and nature and by including environmental protection and improvement in economic policies [22].

Sustainable development in the management of natural resources requires a balance between economic growth, environmental quality, and natural resources $[23,24]$. National income, which is used as the most widespread indicator of the general welfare of countries, does not reflect the qualitative developments affecting the quality of life of the society, especially the environmental values, when evaluating the quantitative aspects of economic development [25]. By determining the economic values and role of natural resources and considering them in the national income calculation, the share of the different sectors in the economy can be determined more accurately. Therefore, it is important to recognize the economic values of natural resources before making policies for their management $[20,23]$ Moreover, as stated by Pak [26], the amount of funds to be allocated for the development of environmental resources (to prevent wastes being thrown into rivers by factories, to ensure that the water used for recreation is clean, etc.) can be determined more realistically if their economic value is determined first [20]. Without considering the link between natural assets and economic added value, the national income calculations may be incomplete or provide biased indications of economic growth [27].

As a consequence of these, some methods have been developed to predict the economic values of the functions of natural resources that currently have no market value. These methods are divided into two groups as direct and indirect methods. Indirect methods follow the course of economic indicators and are based on the values that they express in terms of different environmental factors. Direct methods avoid the potential market hypothesis and allow individuals to express their preferences for environmental commodities through interviews and surveys. One of the most common direct methods is the Conditional Assessment Method. Among the indirect methods, the most commonly used are the Travel Cost Method (TCM) and Hedonic Pricing Method [28]. 
Travel Cost (TC) method and Contingent Valuation (CV) method studies play an important role in natural resource management decisions and have positive effects on people's perception of the environment [29]. TCM and CVM are commonly used to estimate the recreational value of forest areas and national parks [30] and evaluate the value of non-market products or services through people's travel consumption behaviors [31]. TCM was used to determine the direct and indirect values as the recreational value of an island [32], of a lake $[33,34]$, of beaches [35], of urban space [36], the value of fishing spot [37] and ecosystem of national parks [38, 39]. With TCM, users of the park are questioned "how far they have traveled to visit the park", assuming that the economic value of the experience is the same for all users and the user traveling the longest distance to reach. The second model estimates the surplus of the consumer by asking the consumers "what they want to pay in various unexpected situations" [1].

In this study, the economic valuation of recreation areas was carried out in the case of Bozcaada by Individual Travel Cost Analysis. This study indicated that the use of economic valuation methods, such as ITCM, on goods that cannot be evaluated as the environment will contribute to the prevention of environmental destruction for economic rent.

\section{Material and Method}

Bozcaada district is located in Çanakkale in western Turkey (Fig. 1). The island, whose ancient name is Tenedos, has a total surface area of $36.67 \mathrm{~km}^{2}$. The island is located 12 nautical miles south of the Dardanelles and has a great geographical and geopolitical importance.

The island's prominent ecological pattern and agricultural characteristics, as well as traditional culture, are influenced by natural and cultural diversity, richness and dynamism [40]. Bozcaada, which has a rich history, was accepted as a third-degree natural site in 1991. There are also protected areas in the island with different status. Bozcaada is a landscape in which the values it possesses are faced with intense cultural usage. Since it has an extremely limited surface area as an island, protection for the entire island (urbanization, agriculture, tourism, etc.) has always been regarded as the basic principle [41].

Tourism on the island started developing after the 1990s and eventually became an important economic activity. Bozcaada has a great potential in terms of its natural and cultural values, unique historical, and architectural texture, different cultural structures, festivals, vineyards, delicious wines, culinary culture,

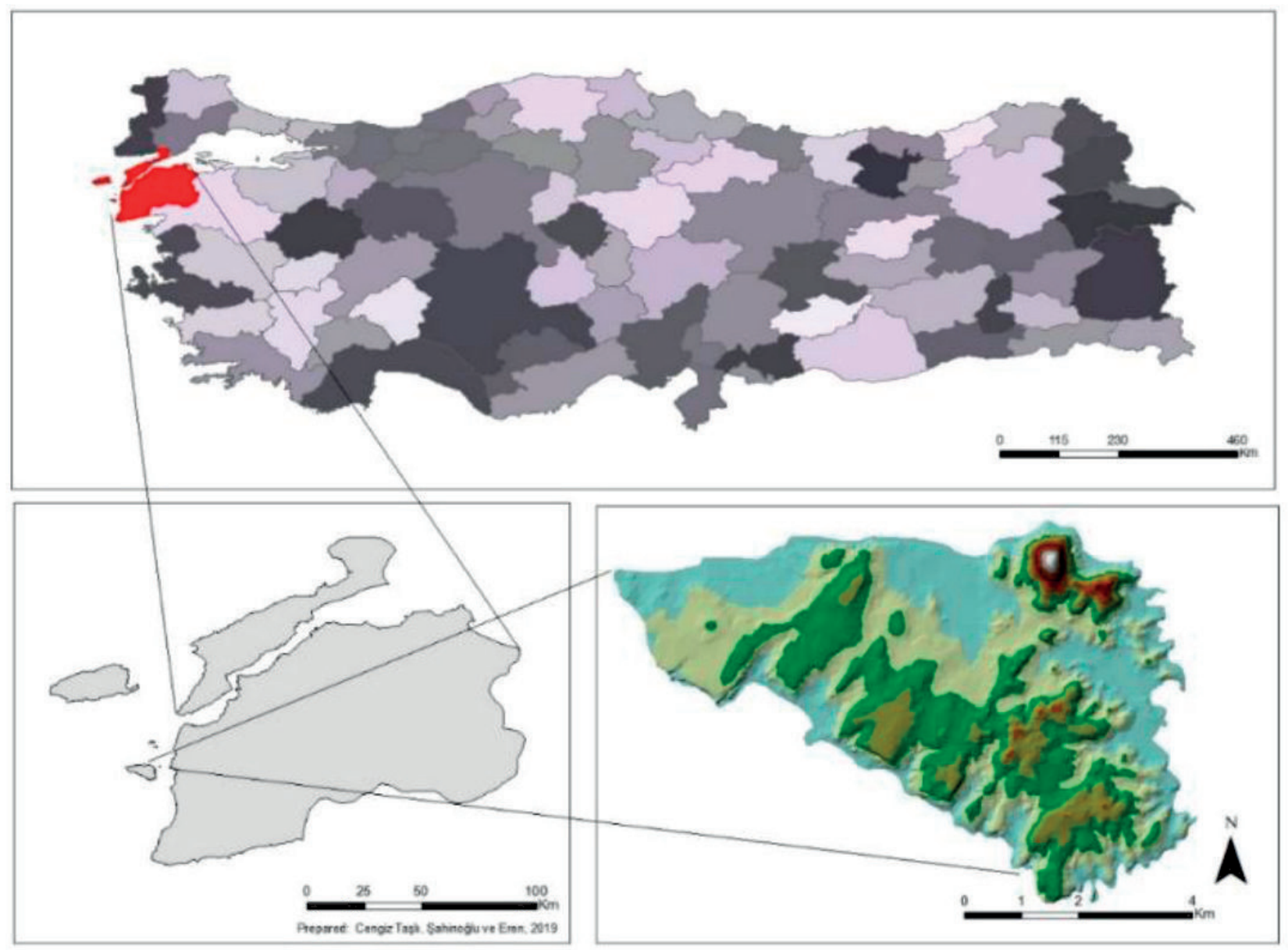

Fig. 1. Location map of Bozcaada. 


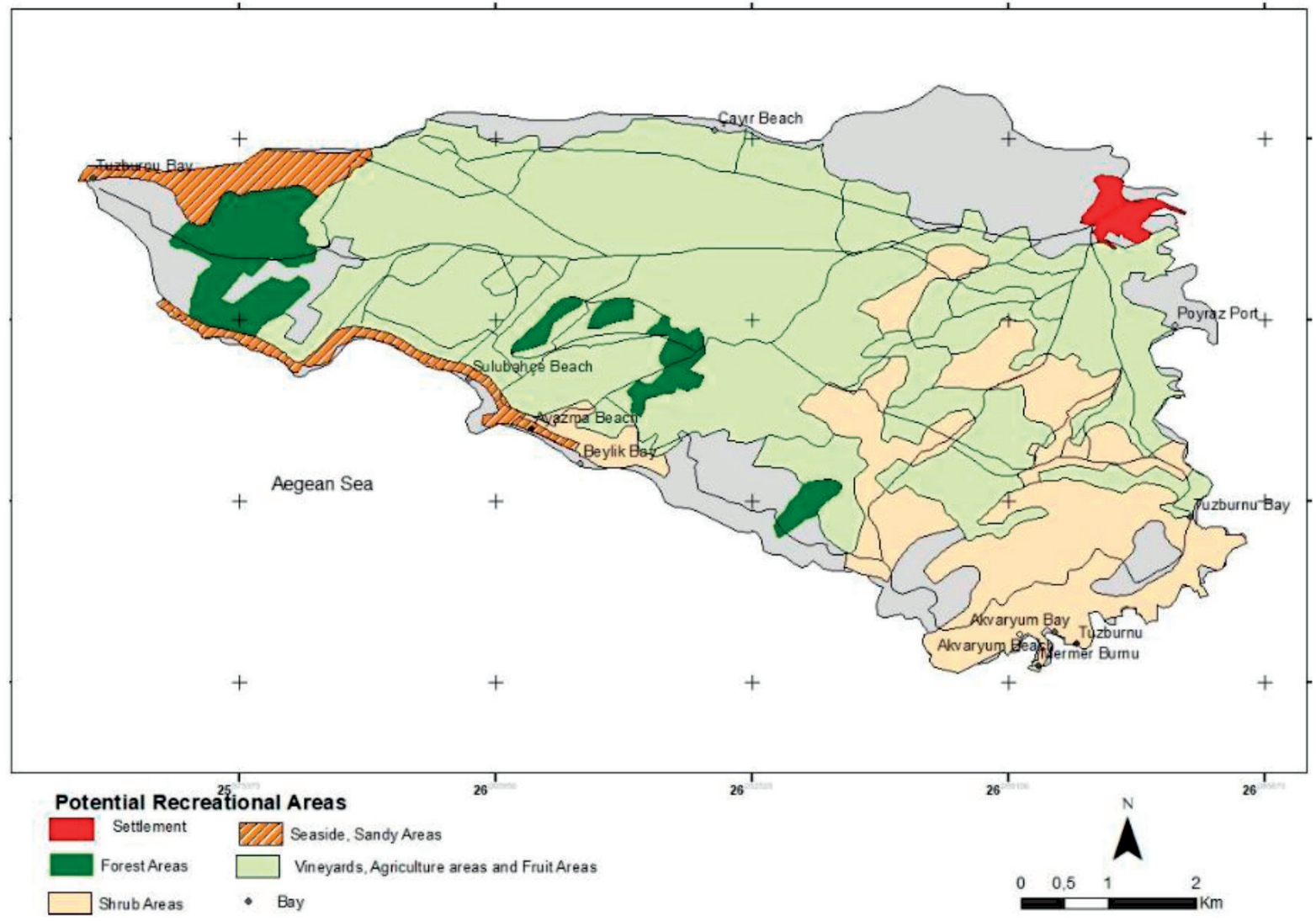

Fig. 2. Recreational area of Bozcaada.

and especially its virgin bays and sea (Fig. 2) [40, 42]. For this reason, especially during the summer months, there is a frequent influx of visitors. Since there is no official record maintained for the number of visitors, it was calculated from the records of the ferry voyages [43] as approximately 1,051,906 visitors/year.

\section{Data and Sources}

As a method of conducting the travel cost analysis, firstly, a total of 200 questionnaires were applied to the visitors at Bozcaada by the random sampling method. In the economic analysis model of Bozcaada, the "Number of Visits" made to the area per year was taken as the dependent variable, while "Travel Expenses", "Participants' Level of Income", Age of participants" and "Vehicle Ownership Status" were taken as independent variables. Semi-logarithmic function type was used for the analysis of consumer rent.

According to the number of visitors to Bozcaada, the survey sample was determined as 200 persons considering a $95 \%$ confidence level $(\mu=0,05)+6.9 \%$ deviation. A total of 200 surveys were randomly carried out (simple incidental sampling) for the visitors. As a result of the analyzes made in the SPSS 21 program, the expenditures that visitors made were correlated with the number of visits per year, and afterward, individual consumer surplus in the field of recreation and the total surplus were calculated. Semi- logarithmic function type was used in the analysis of consumer surplus.

\section{Travel Cost Method Approach}

Natural resources are used extremely for recreational purposes. However, it is often difficult to value these resources because there is usually no price to predict demand functions [44]. Assessment of landscape values requires using indirect methods like travel cost, contingent valuation or hedonic prices [45]. According to many sources that Pak [26] used in his research [46-50], the Travel Cost Method (TCM) aims to estimate the value by examining the consumption movements of ecosystem or recreational areas. The method particularly recognizes the costs incurred on the consumption of the services provided by the environmental resource as their cost [26, 47]. There is no market to directly measure the environmental quality value in order to apply this theory to the observational data. However, the approach adopted for this purpose is generally similar and the measurement is based on the concept of voluntary level of pay [51]. When visitors think that they can draw pleasure in certain recreational activities, they do so by enduring a certain amount of money. However, as we move away from the center of environmental resource, the travel time, thus the cost of travel increases. However, as you move away from the center where an environmental resource is located, the 
travel time will increase, thus the cost of travel. This idea is the main starting point of the travel cost method [20]. Thus the accepted assumption is that according to Bateman and Turner [46], the relationship between demand for space and expenditures made can define a travel-production function.

Various quantitative methods have been applied to evaluate the economic value of recreation and tourism resources as a specific type of non-market goods [52]. TCM is the first way to evaluate the benefits of non-price goods such as outdoor entertainment. Typically it is used to evaluate the value of natural attractions and recreational environments without a market price [53].

TCM is a survey technique which generally provides information about the places of residence; the required demographic and attitude information of visitors, the frequency of visits to the site and other sites examined; the purpose, length, and related costs of the visit, and trip information. From these data, visit costs can be calculated and linked to other factors related to the frequency of visits in order to establish a demand relationship [44].

Torres-Ortega, Pérez-Álvarez [54] describe TCM as containing a wide variety of parameters, including ferry fees, pecuniary values of fuel, entry fees and travel time. And optimization problem presented in TCM is defined as;

\section{$\operatorname{Max} \mathrm{U}(\mathrm{q}, \mathrm{I}, \mathrm{z})$; subject to TC. $\mathrm{q}+\mathrm{z}=\mathrm{I}$}

...where:

U: Utility

q: quantity of a good

I: income

z: consumption of other goods.

Based on this equation, the Marshallian demand for a site is [54],

$$
\mathrm{R}=\mathrm{f}(\mathrm{q}, \mathrm{TC}, \mathrm{z}, \mathrm{I})
$$

As Chae, Wattage [55] used count data regression techniques, calculating the travel demand. Unlike ordinary least-squares (OLS) regression, count data models emphasize the non-negative, integer nature of the data on the number of trips taken, and are most useful when the counts are small [56]. Considering the dependent variable, count data models are generally used in single-site recreation demand estimation. Number of visits to Bozcaada is the dependent variable, and it is generated by a Poisson Process. Mangan, Brouwer [57] mentioned that Poisson regression is a basic count data model that meets discrete probability distribution and non-negative integers. This model is defined as;

$$
\operatorname{Pr}(N=n)=\frac{\lambda^{n}}{n !} e^{-\lambda}
$$

...where $\operatorname{Pr}(\mathrm{N}=\mathrm{n})$ is the probability distribution function of the number of visits $(\mathrm{N}=0,1,2,3, \ldots)$ and $\lambda$ is the function's estimation parameter $(\lambda>0)$. This model can be extended to the regression frame by parameterizing the relationship between the mean $\lambda$ parameter and a set of $\mathrm{x}$ suppressors. An exponential mean parameterization can be used as;

$$
\mathrm{N} \sim \text { Pois }(\lambda=\exp (\mathrm{x} \beta)),
$$

...where $\beta$ is the unknown parameter of the distribution to be estimated for the expected number of visits, according to the characteristics of a visitor, $x$ [57].

In this case, dependent variable is a non-negative integer that is restricted to the number of visitors from the area only once a year. Non-visitors are not included in the sample, therefore it is abbreviated at zero. Zeroabbreviated Poisson can be applied to address the issue of abbreviation. The Poisson distribution abbreviated at zero for the count (n) is presented as;

$$
\operatorname{Pr}(N=n \mid N>0)=\frac{\lambda^{n}}{n !} e^{-\lambda} * \frac{1}{1-e^{-\lambda}}
$$

The researchers, e.g., Tisdell [58] and Bateman and Turner [46], classify TCM as the Individual Travel Cost Method (ITCM) and the Zonal Travel Cost Method according to the definition of the dependent variable $(\mathrm{V})$. The regional TCM is also divided into regions (zones) taking into consideration the settlement places that are visited first. The ratio of the total number of visitors from each region to the total population is considered as a dependent variable. In ITCM, the number of visits to a recreation area of an individual for a certain period of time is a dependent variable $[26,28$, 59]. ITCM can be defined as follows [26];

...where:

$$
V=f(C, X)
$$

$\mathrm{V}$ : The number of visits made during a specific period C: Travel cost

$\mathrm{X}$ : Other socioeconomic variables that explain the value of $\mathrm{V}$ sufficiently.

According to Chae, Wattage [55], consumer surplus is the difference between the willingness to pay and the actual cost. The consumer surplus can be presumable under the utility demand curve for the site.

The demand curve can be expressed as $N=e^{\beta_{0}+\beta_{1}+x_{1}}$, where $\mathrm{N}$ is the number of visits and $\mathrm{X} 1$ is the travel cost for the site. All factors can be considered constant, $\beta_{0}$. The consumer surplus (CS) can be obtained as;

$$
\begin{aligned}
& C S=\int_{X_{1}}^{\infty} e^{\beta_{0}+\beta_{1} X_{1}+\beta_{2} X_{2}+\cdots \varepsilon}=\left[\frac{e^{\beta_{0}+\beta_{1} X_{1}}}{\beta_{1}}\right]_{X_{1}}^{\infty} \\
& =\frac{e^{\beta^{0}+\beta^{1} X_{1}^{\infty}}}{\beta_{1}}-\frac{e^{\beta^{0}+\beta^{1} X_{1}}}{\beta_{1}}=\frac{e^{\frac{\beta^{0}+\beta^{1} X_{1}^{\infty}+\beta^{1} X_{1}}{\beta_{1}}}=-\frac{\bar{N}}{\beta_{1}}}{\beta_{1}}
\end{aligned}
$$


...where $\beta_{1}<0$ is the presumable regression coefficient in reference to travel cost and the number of visits $(\bar{N})$.

\section{Results and Discussion}

In the economic analysis model, the number of visits per year to the area was considered as a dependent variable, while travel cost, income level of participants, age of participants, and vehicle ownership status were taken as independent variables. These factors are exemplified below.

Of the visitors, $48 \%$ stated that they came Bozcaada for the first time in the year and 52\% came 2-5 times. It can be gleaned that the most visitors prefer to come Bozcaada 2-5 times per year.

When the distribution according to the age groups was examined, a significant proportion (41\%) of the participants was between the age of 26 and 35 years. It can also be seen that the values were very close to each other as $21.5 \%$ for the age range of $15-25$ years and $22.5 \%$ for the age range of $36-45$ years. While the age range of $46-55$ years was $10.5 \%$ and the age of 56 and over was only $4.5 \%$. When the distribution according to age groups was examined, it was seen that the young and middle age groups visited Bozcaada more frequently.

A significant proportion of visitors, i.e., 33\%, include individuals with an income of $1000 \mathrm{TL}$ or less; $20 \%$ includes individuals with an income range of $2001-2500 \mathrm{TL} ; 18 \%$ are in the income range of $1501-2000 \mathrm{TL} ; 20 \%$ are with an income range of 2001 TL-2500 TL, and 18\% fall in the income range of $1501-2000 \mathrm{TL}$. Of them, less than 5\% visitors were having an income range of 1000-1500 TL. These results show that the maximum number of visitors $(71 \%)$ belong to the middle-income group. In addition, since mostly students visit Bozcaada, a high number of visitors come in a low-income group.

While $36 \%$ of visitors have one vehicle, $1 \%$ have two vehicles, $63 \%$ of them do not have their own vehicles. While visiting Bozcaada, most of the visitors stated that they came with public transport or rented vehicles.

As a travel cost model, the expenditures made for the transportation for arrival and departure, expenditures made on the road other than transportation, such as food and lodging on the island after arriving in Bozcaada, were taken into consideration.
When examining the expenditures made only for reaching and departing Bozcaada, it was determined that $45 \%$ of the visitors spent about $101-300 \mathrm{TL}, 41.5 \%$ of the visitors spent 100 TL and less; $10 \%$ of the visitors spent about $301-500 \mathrm{TL}, 1.5 \%$ of the visitors spent 501-700 TL and $1.5 \%$ of the visitors spent between 701-900 TL.

When the expenditures made by the visitors in Bozcaada other than transportation were examined, $50.5 \%$ of them stated that they spent $50 \mathrm{TL}$ or less. Further, it was seen that $37.5 \%$ of the visitors spent 51-150 TL, $8 \%$ of spent $151-250 \mathrm{TL}, 1.5 \%$ spent between 251-300 TL, $0.5 \%$ of spent $351-400 \mathrm{TL}$, and about $2 \%$ spent $451 \mathrm{TL}$ or above.

In Bozcaada, $35.5 \%$ of the visitors spent $601-800 \mathrm{TL}$ as the total expenditure including transportation, foodbeverage, accommodation, etc. Among others, 22.5\% spent $801-1000 \mathrm{TL} ; 21 \%$ spent $401-600 \mathrm{TL} ; 9 \%$ spent 201-400 TL; $8 \%$ spent $1001 \mathrm{TL}$ and above, and 4\% spent $200 \mathrm{TL}$ and less.

\section{Application of Model}

Multiple regression analysis and a graded model were applied to determine the effective factors that determine the number of visits made by individuals in a year and determine the recreational use value of Bozcaada with the excess of consumer demand. The regression model can be summarized by the relation $\mathrm{F}$ :

$$
V_{n}=F\left(T_{n}, A_{n}, V_{n}, I_{n}\right)
$$

$V_{n}$. Number of visits

$T_{n}^{n}:$ Travel Expense

$A_{n}$ : Age of Participants

$V_{n}^{n}$. Vehicle Ownership Status

$I_{n}^{n}$ : Income Level of Participants

The dependent variable in the created ITCM model was the "Number of Visits", while "Travel Expense", "Income Level of Participants", "Age of Participants" and "Vehicle Ownership Status" were the independent variables. According to the statistical significance of the results of the regression model, the correlation between these variables was found to be statistically significant at $\mathrm{p}<0.05$ (Table 1).

In addition, according to the TCM, the independent variables "Travel Expense", "Income Level of Participants", "Age of Participants" and "Vehicle

Table 1. Statistical significance of the regression model according to the Travel Cost Method (ANOVA).

\begin{tabular}{|c|c|c|c|c|c|}
\hline Model & Sum of Squares & df & Mean Square & F & $p^{\text {b }}$ \\
\hline Regression & 2.879 & 4 & 0.720 & 2.984 & $0.020^{*}$ \\
\hline Residue & 47.041 & 195 & 0.241 & & \\
\hline Total & 49.920 & 199 & & \\
\hline
\end{tabular}

Note: ${ }^{a}$ Dependent Variable: Number of Visit; ${ }^{\mathrm{b}}$ Predictors: (Constant), Vehicle Ownership, Age, Travel costs, Household income $\mathrm{R}=.240, \mathrm{R}^{2}=.058, \mathrm{sd}=.491 * \mathrm{p}<0.05$ 
Table 2. Coefficients according to the Travel Cost Method.

\begin{tabular}{|c|c|c|c|c|c|}
\hline \multirow{3}{*}{ Model } & \multicolumn{3}{|c|}{ Coefficients $^{\mathrm{a}}$} & \multirow{3}{*}{$\mathrm{t}$} & \multirow{3}{*}{$\mathrm{p}$} \\
\hline & \multicolumn{2}{|c|}{ Unstandardized Coefficients } & \multirow{2}{*}{ Standardized Coefficients } & & \\
\hline & $\beta$ & Std. Error & & & \\
\hline Constant $(\alpha)$ & 1.719 & .154 & & 11.188 & $.000 * *$ \\
\hline Travel costs & -.111 & .052 & -.165 & -2.124 & $.035^{*}$ \\
\hline Household income & -.003 & .024 & -.010 & -.121 & .904 \\
\hline Age & -.090 & .036 & -.191 & -2.464 & $.015^{*}$ \\
\hline Vehicles Ownership & .213 & .084 & .206 & 2.550 & $.012 *$ \\
\hline
\end{tabular}

Notes: ${ }^{a}$ Dependent Variable: Number of Visit

${ }^{*} \mathrm{p}<0.05, * * \mathrm{p}<0.01$

ownership status" explained the variance of dependent variables "Number of Visits" by 5.8\% (Table 1).

Table 2 shows the coefficients used in the ITCM and their significance levels. Accordingly, the relationship between "Number of Visit" and "Travel Expense", "Age of Participants" and "Ownership of Vehicles" was significant at $p<0.05$, while the relationship between "Number of Visits" and "Income Level of Participants" was not statistically significant. It was determined that owning a car had a positive relationship with the number of visits, and the travel cost, whereas the age of the participants was negatively related to the number of visits.

For the semi-logarithmic function type, the consumer surplus was as follows:

Consumer surplus (CS)

$$
\mathrm{CS}=\frac{\bar{N}}{\beta_{S L}}
$$

...where $\bar{N}$ is the average of the total annual number of visits and $\beta S L$ is the curve of the demand function (cost coefficient). Based on this equality, Individual Consumer Surplus was found to be $20.71 \mathrm{TL}$ and total consumer ratio was 2.179.5492,32 TL/year.
It was found that $42 \%$ of the visitors stayed for 4-6 days in Bozcaada once a year; 36.5\% stayed for $1-3$ days; $18 \%$ for $7-9$ days; $3.5 \%$ for 10 days and more. In Table 3, multiple regression analysis of the number of days of stay for each of the independent variables and their significance levels are given. According to this, the relationship between the number of days spent and age groups and vehicle ownership is significant at $p<0.01$ and the relationship with income level is significant at $\mathrm{p}<0.05$ level. There was no statistically significant relationship between the number of days spent and education status and the number of visits. There was a positive relationship between the number of days spent and the level of income and ownership of a vehicle but there was a negative relationship with age groups.

The significance of the variance analysis at $\mathrm{p}<0.01$ indicates that the variance explained by the variable number of days of stay is statistically significant (Table 3). According to the analysis result, age groups, education status, income level, the number of visits and vehicle ownership status of the users account for $34 \%$ of the total variance regarding the number of days spent.

The natural beauty was identified to have the maximum economic value in Bozcaada. This was followed by sea quality, historical structure, civil

Table 3. The results of multiple regression analysis for the number of days of stay for each of the independent variables.

\begin{tabular}{|c|c|c|c|c|c|}
\hline \multirow{3}{*}{ Model } & \multicolumn{3}{|c|}{ Coefficients $^{\text {a }}$} & \multirow{3}{*}{$\mathrm{t}$} & \multirow{3}{*}{$\mathrm{p}$} \\
\hline & \multicolumn{2}{|c|}{ Unstandardized Coefficients } & \multirow{2}{*}{ Standardized Coefficients } & & \\
\hline & $\beta$ & Std. Error & & & \\
\hline Constant $(\alpha)$ & 1.258 & .403 & & 3.119 & $.002 *$ \\
\hline Age & -.273 & .068 & -.355 & -4.032 & $.000 * *$ \\
\hline Education level & -.196 & .110 & -.147 & -1.780 & .077 \\
\hline Household income & .109 & .035 & .227 & 3.076 & $.002 *$ \\
\hline Number of Visit & .185 & .113 & .109 & 1.637 & .103 \\
\hline Vehicles Ownership & .798 & .097 & .486 & 8.194 & $.000 * *$ \\
\hline
\end{tabular}

Notes: a Dependent Variable: Number of Days of Stay ${ }^{*} \mathrm{p}<0.05, * * \mathrm{p}<0.01$ 
Table 4. The values that Bozcaada possesses.

\begin{tabular}{|c|c|c|}
\hline Values & Mean & Std. Error \\
\hline Sea Quality & 4,64 &, 513 \\
\hline Quality of the Beach & 4,01 &, 642 \\
\hline Natural Beauty & 4,68 &, 490 \\
\hline Civil Architecture & 4,31 &, 611 \\
\hline Historical Structure & 4,53 &, 641 \\
\hline Note: $\mathrm{N}=200$ & & \\
\hline
\end{tabular}

Table 5. Quality of facilities and service in Bozcaada.

\begin{tabular}{|c|c|c|}
\hline Facility and service & Mean & Std. Error \\
\hline Visitor quality and density & 3,70 &, 703 \\
\hline The appropriateness of the ferry fee & 3,24 &, 904 \\
\hline Shopping units (buffet, restaurant) & 3,50 &, 672 \\
\hline Promotion of local products & 3,79 &, 572 \\
\hline Consulting services & 3,42 &, 725 \\
\hline
\end{tabular}

Note: $\mathrm{N}=200$

architecture, and beach quality (Table 4). There was no significant relationship between the values of Bozcaada and age, gender and income groups with the F- and t-tests performed $(\mathrm{p}>0.05)$.

When the quality of the facility and service in Bozcaada was questioned, it was seen that the highest value is the promotion of local products. This is followed by visitor quality and density, shopping facilities (buffet, restaurant), counseling services, and ferry fees (Table 5). As a result of the F- and t-tests conducted, there was no significant relationship between age, gender, and income groups in terms of evaluating facility and service quality $(\mathrm{p}>0.05)$.

\section{Conclusions}

This study along with the others that set an example for the determination of the economic value of nonmarketable natural assets in terms of recreation and tourism will enable both national income and growth values to be determined more rationally than the current situation. In addition, recreational and economic evaluation of natural areas is also important in terms of ensuring the sustainability of recreational and naturefriendly tourism activities. This point of view will prevent the destruction of the surrounding area with rent anxiety. It will ensure the preservation, planning, and management of natural areas in the future.

As the most common methods for determining the economic value of natural areas, travel cost method (regional and individual), conditional valuation method, and hedonic price method have been used [51, 60, 61]. One of these methods, "Individual Travel Cost Method", was applied as a model in this study. As with other methods, there are some difficulties in this model as well. The problems related to the method could be outlined in five main headings [51]. These are defined as the problems arising from the definition of travel cost and travel-related data, problems arising from the identification of the data that reveal the socio-economic structure of the user, problems arising from the definition of the recreational possibilities of the area, the problems arising from the identification of the demand structure identified using the expected data described under the first three headings, and finally, estimation problems based mainly on econometric reasons. Özbek [62] expressed difficulties in implementing this approach in terms of difficulty in assessing travel time and collecting data. For this reason, in many studies, the model is analyzed with different factors. The variability of these factors also affects the results of the studies. For example, Ortaçeşme, Özkan [59] considered only fuel expenses as travel expenses in the study. Further, Başar [25] considered the total cost of traveling by a private vehicle, the cost of the goods they bring with them, the entrance fee to the park, and another spending in the park, which are the basic independent variables of the study. In the model, three different approaches were used to calculate the transportation cost and time value. In many studies, in addition to the fuel cost, vehicle's insurance, depreciation etc. can be included in terms of transportation. The fuel cost can be calculated by using fuel consumption change according to the type of vehicle and the distance data.

Bateman and Turner [46] specified three methods that can be used to determine travel cost. They calculated the marginal expenditure only by considering fuel costs and calculated fuel cost by adding fixed expenses such as insurance costs, depreciation, and maintenance expenses, and finally added the expenditures expressed by individuals in surveys [27]. However, the credibility of this information depends on the individual perception of expenditure and on the correct interpretation of the questions posed by the consumer. Ortaçeşme, Özkan [28] emphasized that in calculating the economic value of the time spent in Turkey, there is no value to be taken as a basis; however, various approaches have been adopted in studies carried out in other relevant countries. For this reason, researchers are having difficulty in including the opportunity cost into their calculations. Because of this ambiguity, the question of the opportunity cost of time is questioned in the model.

The factors discussed in this study have been tried with different combinations. The statistically significant correlation between the factors was used in the economic analysis model. In this research, travel expenses were considered as expenditure for transportation on arrival and departure, expenditure 
for non-transportation on travel and expenditures made for transportation, food-beverage, accommodation, etc., after arriving Bozcaada. In addition to the travel costs, the income level, age, and vehicle ownership were taken as the constitutive factors in the model. Since the research area is very dense during the summer season, the quality of the sea is very good and the carrying capacity is quite high, thus the surveys were conducted during the summer. During the winter months, the hard winds and climate of the Çanakkale cause the access to the island to be very difficult and accessibility to Bozcaada via ferry is very limited in the winter months. For this reason, year-round surveys were ignored. However, in such studies, surveys throughout the year, depending on the characteristics of the place, may be designed for other investigation.

\section{Discussion}

In the study, the determination of the economic value of Bozcaada, which is rich in natural and cultural characteristics, the total consumer surplus could be calculated approximately. Since the number of visitors to Bozcaada is not recorded strictly, the annual number of visitors was calculated from the statistics used in the ferry service [43]. Only the statistics about the number of vehicles cause the uncertainty of how many people pass through the vehicles. The ticket statistics of pedestrian passengers during ferry crossings are definite, but the lack of definition of the visitors in vehicles and the characteristics of the vehicles in ferry, and inability to keep statistics cause chaos. Therefore, only the estimated data could be considered in determining the total number of visitors and the total consumer surplus. However, despite these limitations, emphasizing the conservation and the importance of natural areas, which will bring economic benefits, reveals the importance of such researches.

As a result of the analyses made, the approximate total consumer surplus value for Bozcaada was found to be $21,795,492.32 \mathrm{TL} /$ Year according to ITCM. Also, the highest value factor that Bozcaada has in terms of recreation and tourism was determined as natural beauty. This was followed by the quality of the sea, the historical structure, the civil architecture and the quality of the beach, respectively. The highest value in terms of facility and service quality in Bozcaada was found to be the promotion of local products. This is followed by visitor quality and density, shopping facilities (buffet, restaurant), consultation services and ferry fares.

In this study, the relationship between landscaping areas and economy is revealed and the feasibility of economic analysis of natural resources with ITCM is exemplified. It is thought that such research could contribute to the sustainability of natural areas and in making environmentally sensitive political decisions, planning processes, and application processes.

\section{Acknowledgement}

This project was supported by the project FYL-2015472 by Çanakkale Onsekiz Mart University Scientific Research Projects (ÇOMU BAP) Coordination Unit. We would like to extend our gratitude to the ÇOMU BAP Unit for the realization of the research. At the same time, we thank each participant who responded to the questionnaires.

\section{Conflict of Interest}

The authors declare no conflict of interest.

\section{References}

1. ALMEIDA F.P., RIBEIRO F.A.B.S., DE LIMA M.K.G., DE GOUVEIA R.G.L., FOGAÇA L.B.V. Evaluation of the Visitation Rate in the Park by the Travel Cost Method in Parque Do Sabiá Complex, Uberlândia, Minas Gerais, Brazil. International Journal of Advanced Engineering Research and Science, 6 (6), 2019.

2. DONG S., CHENG H., LI Y., LI F., WANG Z.,CHEN F. Rural landscape types and recreational value spatial analysis of valley area of Loess Plateau: A case of Hulu Watershed, Gansu Province, China. Chinese Geographical Science, 27 (2), 286, 2017.

3. HAINES-YOUNG R., POTSCHIN M. Common international classification of ecosystem services (CICES, Version 4.1). European Environment Agency, 33, 107, 2012.

4. HERMES J., VAN BERKEL D., BURKHARD B., PLIENINGER T., FAGERHOLM N., VON HAAREN C., ALBERT C. Assessment and valuation of recreational ecosystem services of landscapes. Ecosystem Services, 31 Part C, 289-295, 2018.

5. KULCZYK S., WOŹNIAK E., DEREK M. Landscape, facilities and visitors: An integrated model of recreational ecosystem services. Ecosystem services, 31, 491, 2018.

6. MILCU A.I., HANSPACH J., ABSON D., FISCHER J. Cultural ecosystem services: a literature review and prospects for future research. Ecology and society, 18 (3), 2013.

7. HERNÁNDEZ-MORCILLO M., PLIENINGER T., BIELING C. An empirical review of cultural ecosystem service indicators. Ecological indicators, 29, 434, 2013.

8. BOEREMA A., REBELO A.J., BODI M.B., ESLER K.J., MEIRE P. Are ecosystem services adequately quantified? Journal of Applied Ecology, 54 (2), 358, 2017.

9. DE GROOT R.S., ALKEMADE R., BRAAT L., HEIN L., WILLEMEN L. Challenges in integrating the concept of ecosystem services and values in landscape planning, management and decision making. Ecological complexity, 7 (3), 260, 2010.

10. EZEBILO E.E. Economic value of a non-market ecosystem service: an application of the travel cost method to nature recreation in Sweden. International Journal of Biodiversity Science, Ecosystem Services \& Management, 12 (4), 314, 2016.

11. AMBARITA S., BASYUNI M., SULISTYONO N., WATI R., FITRI A., SLAMET B., BALKE T., BUNTING P., MUNIR E. Landscape planning and economic valuation 
of mangrove ecotourism using GIS and Google Earth image. Journal of Theoretical and Applied Information Technology, 96 (19), 2018.

12. BAKHSH K., MESHAAL I., RIAZ H. Evaluating visitors' travel demand and recreational values in Kallar Kahar Lake, Pakistan. Environment, Development and Sustainability, 1-17, 2019.

13. HESLINGA J., GROOTE P., VANCLAY F. Understanding the historical institutional context by using content analysis of local policy and planning documents: Assessing the interactions between tourism and landscape on the Island of Terschelling in the Wadden Sea Region. Tourism Management, 66, 180, 2018.

14. STEPHEN F.M., SPENCELEY A. Tourism and protected areas: A growing nexus of challenge and opportunity. Koedoe, 56 (2), 1, 2014.

15. LIBOSADA JR C.M. Business or leisure? Economic development and resource protection - Concepts and practices in sustainable ecotourism. Ocean \& Coastal Management, 52 (7), 390, 2009.

16. FREDMAN P., TYRVÄINEN L. Frontiers in naturebased tourism. Scandinavian Journal of Hospitality and Tourism, 10 (3), 177, 2010.

17. DEREK M., WOŹNIAK E., KULCZYK S. Clustering nature-based tourists by activity. Social, economic and spatial dimensions. Tourism Management, 75, 509, 2019.

18. YANG J., GE Y., GE Q., XI J., LI X. Determinants of island tourism development: the example of Dachangshan Island. Tourism Management, 55, 261, 2016.

19. ZANDI S., LIMAEI S.M., AMIRI N. An economic evaluation of a forest park using the individual travel cost method (a case study of Ghaleh Rudkhan forest park in northern Iran). Environmental \& Socio-economic Studies $6(2), 48,2018$.

20. GÜNDOĞMUŞ M.E., KALFA V.R. Piyasa Değeri Olmayan Varlıkların Ekonomik Değerinin Belirlenmesi. Journal of Life Economics, 3 (4), 177, 2016 [In Turkish].

21. GÖRÜCÜ Ö., KAYA M.E. Ilgaz Dağ1 Milli Parkında Rekreatif Kullanımların Ekonomik Analizi, IV. Ormanc1lıkta Sosyo-Ekonomik Sorunlar Kongresi 15-17 Ocatober 2015, Trabzon, 2015 [In Turkish].

22. ALTUNKASA F. Çevrenin Ekonomik Değeri, Lisansüstü Ders Notu, Vol., Adana, Çukurova Üniversitesi Ziraat Fakültesi Peyzaj Mimarlığı Bölümü, 2008.

23. MURYANI U. An Economic Valuation of Ecotourism Using Travel Cost Method Approach. International Journal of Research in Advent Technology, 4 (12), 2016.

24. PEARCE D.W., TURNER R.K. Economics of natural resources and the environment, JHU Press, 1990.

25. BAŞAR H. Dilek Yarımadası-Büyük Menderes Deltası Milli Parkının Rekreasyon Amacıyla Kullanımının Ekonomik Değerin Saptanmasi: Bir Seyahat Maliyet Yöntem Uygulaması, Ege Üniversitesi Fen Bilimleri Enstitüsü, Adana, Yüksek Lisans Tezi, 2007 [In Turkish].

26. PAK M. Orman Kaynağından Rekreasyonel Amaçlı Yararlanmanın Ekonomik Değerinin Tahmin Edilmesi ve Bu Değer Üzerinde Etkili Olan Değişkenler Üzerine Bir Araştırma Karadeniz Teknik Üniversitesi Fen Bilimleri Enstitüsü, Trabzon, Doktora Tezi, 2002 [In Turkish].

27. BELKAYALI N. Yalova Termal Kaplicalarının Rekreasyonel ve Turizm Amaçlı Kullanımının Ekonomik Değerinin Belirlenmesi, Ankara Üniversitesi Fen Bilimleri Enstitüsü, Ankara Doktora Tezi, 2009 [In Turkish].

28. ORTAÇEŞME V., ÖZKAN B., KARAGÜZEL O., ATIK M., AKPINAR M. Kurşunlu Şelalesi Tabiat Parkının
Ekonomik Değerinin Saptanması, Vol., TÜBİTAK Proje Raporu No: TARP-2152., 1999 [In Turkish].

29. XIAO Y., CHENG C., YANG W., OUYANG Z., RAO E. Evaluating Value of Natural Landscapes in China. Chinese Geographical Science, 26 (2), 244, 2016.

30. YUZBASHKANDI S.S., MEHRJO A. Estimating the recreational values of forest park using the contingent valuation method (case study: Kabudval Forest Park, Golestan Province of Iran). Journal of Forest Science, $\mathbf{6 5}$ (12), 472, 2019.

31. YUAN L.-L., WANG S.-J. Recreational value of glacier tourism resources: A travel cost analysis for Yulong Snow Mountain. Journal of Mountain Science, 15 (7), 1446, 2018.

32. WEIQI C., HUASHENG H., YAN L., ZHANG L., XIAOFENG H., RAYMOND M. Recreation demand and economic value: An application of travel cost method for Xiamen Island. China Economic Review, 15 (4), 398, 2004.

33. JALA, NANDAGIRI L. Evaluation of economic value of pilikula lake using travel cost and contingent valuation methods. Aquatic Procedia, 4, 1315, 2015.

34. FLEMING C.M., COOK A. The recreational value of Lake McKenzie, Fraser Island: An application of the travel cost method. Tourism Management, 29 (6), 1197, 2008.

35. ZHANG F., WANG X.H., NUNES P.A., MA C. The recreational value of gold coast beaches, Australia: An application of the travel cost method. Ecosystem Services, 11, 106, 2015.

36. HANAUER M.M., REID J. Valuing urban open space using the travel-cost method and the implications of measurement error. Journal of environmental management, 198, 50, 2017.

37. POKKI H., ARTELL J., MIKKOLA J., ORELL P.,OVASKAINEN V. Valuing recreational salmon fishing at a remote site in Finland: A travel cost analysis. Fisheries Research, 208, 145, 2018.

38. MAYER M., WOLTERING M. Assessing and valuing the recreational ecosystem services of Germany's national parks using travel cost models. Ecosystem Services, 31, 371,2018

39. TUAN N.T., CHI T.T., VAN Y T., MUNG V.T. Recreational and conservative valuation of Bien Ho landscape. Vietnam Journal Of Earth Sciences 41 (2), 156, 2019.

40. CENGIZ T. Visual quality method in assessing landscape characteristics: Case study of bozcaada island. Journal of Coastal Research, 30 (2), 319, 2014.

41. KAPTAN AYHAN Ç. Özgün Peyzaj Karakteristiklerine Sahip Mekanlara Yönelik Bir Peyzaj Planlama Yönteminin Ortaya Konulmas1, Ege Üniversitesi Fen Bilimleri Enstitüsü, İzmir, Doktora Tezi, 2007 [In Turkish].

42. Bozcaada District Governorship Official Website. Available online: http://www.bozcaada.gov.tr (accessed on September 2017).

43. ANONYMUS. GESTAŞ Deniz Ulaşım Turizm Ticaret Anonim Şirketi, Bozcaada 2016 Statistical Data for Ferry Transportation. Çanakkale, 2017.

44. DAS S. Travel cost method for environmental valuation. Center of Excellence in Environmental Economics, Madras School of Economics, Dissemination Paper, 23, 2013.

45. MOLINA J.R., Y SILVA F.R. Valuation of the economic impact of wildland fires on landscape and recreation resources: a proposal to incorporate them on damages valuation, Gen. Tech. Rep. PSW-GTR-261 (English), Vol. 261, Albany, CA:US Department of Agriculture, Forest Service, Pacific Southwest Research Station, 228, 2019. 
46. BATEMAN I., TURNER R. Valuation Of The Environment, Methods And Techniques. Sustainable environmental economics and management; R. Turner, Eds, Belhaven Press: London, 192, 1993.

47. DANEV G. Guidelines For The Economic Evaluation of Natural Assets of The Protected Areas, M. Ruzzier, Vol., Ljubljana, Institute of the Republic of Slovenia for Nature Conservation, 2010.

48. GEORGIOU S., WHITTINGTON D., PEARCE D., MORAN D. Economic Values And The Environment In The Developing World, Edward Elgar Publishing Ltd: UK, 1997.

49. HANLEY N.D., RUFFELL R. The Contingent Valuation Of Forest Characteristics: Two Experiments. Journal of Agricultural Economics, 44 (2), 218, 1993.

50. KULA E. Economics Of Natural Resources, The Environment And Policies, Chapman\&Hall Press: UK, 1994.

51. ALKAY E., OCAKÇI M. Kentsel Yeşil Alanların Ekonomik Değerlerinin Ölçülmesinde Kullanılabilecek Yöntemlerin İrdelenmesi. İTÜDERGİSİ/a, 2 (1), 60, 2003 [In Turkish].

52. JONES T.E., YANG Y., YAMAMOTO K. Assessing the recreational value of world heritage site inscription: A longitudinal travel cost analysis of Mount Fuji climbers. Tourism Management, 60, 67, 2017.

53. ZHANG P. Tourism Value Evaluation of Urban Ancient Architecture. Current Urban Studies, 7 (2), 157, 2019.

54. TORRES-ORTEGA S., PÉREZ-ÁLVAREZ R., DÍAZSIMAL P., DE LUIS-RUIZ J., PIÑA-GARCÍA F. Economic Valuation of Cultural Heritage: Application of Travel Cost Method to the National Museum and Research Center of Altamira. Sustainability, 10 (7), 2550, 2018.
55. CHAE D.-R., WATTAGE P., PASCOE S. Recreational benefits from a marine protected area: A travel cost analysis of Lundy. Tourism Management, 33 (4), 971, 2012.

56. ENGLIN J.E., HOLMES T.P., SILLS E.O. Estimating forest recreation demand using count data models. Forests in a market economy; Eds, Springer: 341, 2003.

57. MANGAN T., BROUWER R., LOHANO H.D., NANGRAJ G.M. Estimating the recreational value of Pakistan's largest freshwater lake to support sustainable tourism management using a travel cost model. Journal of Sustainable Tourism, 21 (3), 473, 2013.

58. TISDELL C.A. Economics Of Environmental Conservation, Elsevier Science Publisher: Amsterdam, Holland., 1, 359, 1991.

59. ORTAÇEŞME V., ÖZKAN B.,KARAGÜZEL O. An Estimation Of The Recreational Use Value Of Kursunlu Waterfall Nature Park By The Individual Travel Cost Method. Turkish Journal of Agriculture and Forestry, 26 (1), 57, 2002.

60. TALAY İ., AKPINAR N., BELKAYALI N. Doğal Kaynakların Rekreasyonel ve Turizm Amaçlı Kullanımının Ekonomik Değerinin Tespiti: Göreme Tarihi Milli Parkı Örneği. Coğrafi Bilimler Dergisi, 8 (2), 137, 2010 [In Turkish].

61. WILLIS K.G., GARROD G.D. Valuing Landscape: A Contingent Valuation Approach. Journal of Environmental Management, 37 (1), 1, 1993.

62. ÖZBEK A. Doğal Kaynaklar Ekonomisi ve Sürdürülebilirlik Bağlamında Çevre ve Ekolojik (Yeşil) Ekonomi Tarihi: 1960-1980, Marmara Üniversitesi Sosyal Bilimler Enstitüsü, İstanbul, Yüksek Lisans Tezi, 2016 [In Turkish]. 